Article

\title{
Sovereignty of the Living Individual: Emerson and James on Politics and Religion
}

\author{
Stephen S. Bush
}

Department of Religious Studies, Brown University, 59 George Street, Providence, RI 02912, USA; stephen_bush@brown.edu

Received: 20 July 2017; Accepted: 20 August 2017; Published: 25 August 2017

\begin{abstract}
William James and Ralph Waldo Emerson are both committed individualists. However, in what do their individualisms consist and to what degree do they resemble each other? This essay demonstrates that James's individualism is strikingly similar to Emerson's. By taking James's own understanding of Emerson's philosophy as a touchstone, I argue that both see individualism to consist principally in self-reliance, receptivity, and vocation. Putting these two figures' understandings of individualism in comparison illuminates under-appreciated aspects of each figure, for example, the political implications of their individualism, the way that their religious individuality is politically engaged, and the importance of exemplarity to the politics and ethics of both of them.
\end{abstract}

Keywords: Ralph Waldo Emerson; William James; transcendentalism; individualism; religious experience

\section{Emersonian Individuality, According to James}

William James had Ralph Waldo Emerson in his bones. ${ }^{1}$ He consumed the words of the Concord sage, practically from birth. Emerson was a family friend who visited the infant James to bless him. James's father read Emerson's essays out loud to him and the rest of the family, and James himself worked carefully through Emerson's corpus in the 1870's and then again around 1903, when he gave a speech on Emerson (Carpenter 1939, p. 41; James 1982, p. 241). A number of key ideas are central to the thought of both: individuality and self-reliance; the dangers of conformity and docility; the primary importance of experience and action; a sense for individual and collective possibility; a high regard for the moral life; a commitment to the task of perfecting one's moral character, ${ }^{2}$ and a vital link between morality and religion. James of course does not line up with Emerson wholesale, that would be a wholly inappropriate stance to take vis-à-vis one who says that "imitation is suicide" (Emerson 1983, p. 259). He has his points of disagreement. In particular, he rejects the cosmic monism, non-empirical intuitionism, and abstract ideality that he associates with Emerson's transcendentalism (Carpenter 1939, pp. 42-43, 49-56).

But they have much in common. To be sure, their points of agreement deal with themes that were in the air in nineteenth-century North Atlantic intellectual culture, and it is possible that James arrived at his insights through other sources or that "he discovered them for himself" (Carpenter 1929, p. 458). Without attempting to settle the lines of influence decisively, I follow those who regard Emerson as a significant influence on James in particular and pragmatism in general. ${ }^{3}$ We should take James

1 He writes in his diary, "I am sure that an age will come ... when Emerson's philosophy will be in our bones." Quoted in (McDermott 1982, p. xxi).

2 Emerson's perfectionism is well known, thanks in considerable part to (Cavell 1990). James's perfectionism is not as widely acknowledged. For discussions of his commitment to moral self-cultivation, see (Slater 2009, 142ff.; Bush 2017, chp. 5).

3 See, for example, (West 1989; McDermott 2007, pp. 88-105; Perry 1935; Albrecht 2012). 
seriously at his word in calling Emerson "exquisite," his "beloved Master" (James 1982, p. 115), and, with colloquial affection, "really a critter to be thankful for" (Carpenter 1929, p. 472). Whether James derived his view of the individual from Emerson exclusively, derived it from Emerson as one primary influence among other influences, or found affirmation in Emerson for views he gleaned otherwise, at the very least James worked through his doctrine of the individual with Emerson in mind, and he arrived at the same conceptual terrain as Emerson on this and related matters. In this essay, I will argue that this is so by considering their respective accounts of individuality, noting how both of them relate individuality to politics and religion in similar ways. I will challenge some prevailing ideas about both the political and religious implications of the individuality of each of these two giants of American thought, showing that Emerson's and James's individuality is more political than many accounts allow.

Any attempt to compare Emerson and James on a given topic is complicated by the fact that for both of these figures, no consensus exists among interpreters on how we are to understand their individualism, their politics, and their religiosity. Emerson in particular is difficult to pin down. His individualism has been claimed by anti-democrats, radical democrats, liberals, and libertarians. His religious commitments have been pegged as naturalist, super-naturalist, pantheistic, and irreligious. ${ }^{5} \mathrm{He}$ is a brilliant stylist and rhetorician, more interested in unsettling and provoking his audience than in laying out a coherent system of thought on any topic. He slyly warns his readers not to expect from his oeuvre quick and tidy positions on any topic: "a foolish consistency is the hobgoblin of little minds" (Emerson 1983, p. 265). Since the scope of the present essay precludes exhaustive exposition of Emerson's corpus, the question is, whose Emerson will serve as the counterpart to James in this comparative exercise? My starting point (though not the exclusive frame of reference) will be to engage with Emerson as James understands him, since this is a version of Emerson we must grapple with anyways to understand the relation between the two, and it is a topic of interest in its own right. As for the relevant understanding of James, here I will rely on the textual and argumentative work that I have done elsewhere (Bush 2015, 2017).

James makes numerous references to Emerson throughout his published oeuvre and his correspondence, but most of them are brief. His most extensive reflections on Emerson come primarily from two primary sources, both produced at roughly the same time, Varieties of Religious Experience (delivered as lectures in 1901 and 1902) (James 1985) and his address on Emerson at the centenary celebration of Emerson's birth (1903) (James 1982, pp. 109-15). ${ }^{6}$ We will also consider two passing but significant mentions of Emerson in "On a Certain Blindness in Human Beings" (James 1983, pp. 132-49).

James's sole dedicated treatment of Emerson's thought comes in his contribution to the centenary celebration of Emerson's birth, a speech delivered on 25 May 1903, at Concord, Massachusetts. The essay is brief (it was a twenty-minute speech), and it is easy to overlook the richness of the substance therein. Indeed, John McDermott says, "with regard to the influence of Emerson on James, the address is disappointing," and in McDermott's view, it is concerned with only one theme, "possibility," which comes by "the hallowing of the everyday" (McDermott 2007, p. 99). In contrast, I see a richer, more substantial account both of Emerson's key themes, as James understands them, and of Emerson's influence on James. When James identifies what for him is "the soul" of Emerson's message, it is the "sovereignty of the living individual" (James 1982, p. 112). And in addition to the topic of individuality, two other prominent related topics emerge, that of receptive attention

4 Furthermore, as Carpenter points out, it is not just that James read Emerson in the 1870's, he read and reread him, with copious notes: "[James's first two volumes of Emerson's writings] have obviously been read many times ... Almost every page of the text is underlined or annotated." (Carpenter 1939, p. 41).

5 For a helpful survey of the secondary literature on Emerson's religious identity, see (Friesner 2017, chp. 2).

6 For a helpful survey of a number of James's references to Emerson on a broader range of topics, see (Stafford 1953, pp. 433-61; Perry 1935). 
(which corresponds to McDermott's "hallowing of the everyday") and vocation. We will treat each of these in turn, and later, as we shall see, all of them will prove to have political and religious implications.

What sort of individuality does James attribute to Emerson? It is that of (as in the title of Emerson's famous essay) "self-reliance." "The only way to be true to our Maker," James explains, "is to be loyal to ourselves." He continues, "there is something in each and all of us, even the lowliest, that ought not to consent to borrowing traditions and living at second hand (James 1982, p. 111). Self-reliance has to do with a constellation of attitudes toward self and others. Principally, one regards oneself as the primary authority in various domains of one's life: epistemically, religiously, morally, and politically. One does not defer unthinkingly to the opinion of anyone else on these matters. This is not to say that one ignores the testimony or authority of others, whether one's peers, institutional officials, or the ancient traditions, it is just to say that one considers the proposals that these make in light of one's own values, experiences, aims, and personal history. To live at second hand is to take part in routines and habitual ways of thinking and acting simply because one has been socialized into them or instructed to do so. James quotes Emerson from "Self-Reliance": "Imitation is suicide" (James 1982, p. 111; Emerson 1983, p. 259). Emerson counsels that we reflect critically on the routines, values, and social roles that shape our personalities and institutions. As James explains, "This faith that in a life at first hand there is something sacred is perhaps the most characteristic note in Emerson's writings" (James 1982, p. 111). A first-hand life is one in which one counts one's own experiences, one's own history, and one's own aims as principal factors as one deliberately and responsibly forms for oneself the values and ideals that guide one's conduct and activities.

Of course relying on oneself requires that one cultivate the sort of self who is worthy of self-reliance, and this is no more so true than when it comes to the matter of experience. This brings us to the topic of receptive attention. Individuality means that one has one's own vantage point in the world, and thus requires that one attend to one's surroundings with care. "The individual open[s] thus directly into the Absolute," James says (James 1982, p. 111). That is, living first hand means acknowledging that all of us can perceive, for ourselves, truth. It is careful perception of the details that surround us, with the recognition that universal themes are apprehensible therein. We are to give ourselves to "seeing freshly" (James 1982, p. 111). "There are times when the cawing of a crow, a weed, a snow-flake, or a farmer planting in his field, become symbols to the intellect of truths equal to those which the most majestic phenomena can open. Let me mind my own charge, then, walk alone, consult the sky, the field and forest, sedulously waiting every morning for the news concerning the structure of the universe which the good Spirit will give me" (James 1982, p. 110). Emerson is a "seer," one who has the capacity to appreciate, in the specific situations that surround one, that one is interconnected with one's environment, intimately in touch with the moral and spiritual structure of the world. The "individual fact and moment" are "suffused with absolute radiance" (James 1982, p. 114). The first-hand familiarity with moral, religious, and aesthetic realities is key to Emersonian individuality, and Emerson calls us all to pursue it.

Also key to Emersonian individuality is fealty to one's particular vocation. One must have a sense for oneself of what one's role is, what one's duties are, and what ideals serve as the ends of one's life. "The individual must in reason be adequate to the vocation for which the Spirit of the world has called him into being," James writes. People must "be incorruptibly true to their own private conscience," determining for themselves their "appointed place and character" (James 1982, p. 112). This too is a first-hand, as opposed to a second-hand life. We must reject any unthinking accommodation to the roles others would design for us or assign to us. We should live from a clear sense of what our own contributions to the world will be. Emerson himself refused all causes and associations, no matter how worthy, that were not in keeping with his particular insights, aptitudes, and aims (James 1982, pp. 110,115). His duty was "spiritual seeing and reporting," and his reporting took the form of his speeches and essays, fashioned with such style that James calls him an "Artist" (James 1982, p. 110). That was Emerson's vocation, others must find their own. And it is no easy task, one must pursue one's vocation, grow into it. One must be "authentic" and "genuine" if one is to 
enjoy the "indefeasible right to be exactly what one is." No matter what one's vocation is, so long as one executes it with faithfulness, no one is "insignificant" (James 1982, p. 113). This vocation is not merely for one's own self-enhancement or private pleasure, rather it has to do with one's contribution to the society in which one lives. One's character and activities are necessarily publicly expressed, they have an effect on those around one. One's thoughts "publish themselves to the universe" (James 1982, p. 113). One's deeds are a "proclamation," the onlooker will "greet and accept [them]" (James 1982, p. 113).

In treating these three themes-individuality, receptive attention, and vocation-in his centenary address, James speaks of Emerson's religiosity. Every person participates in the "Cosmic Intellect" and has direct access to the "Absolute" (James 1982, p. 111). Quoting Emerson from his poem "Voluntaries," James states Emerson's creed as, "So nigh is grandeur to our dust/So near is God to man!" (James 1982, p. 111). For Emerson, "Divinity is everywhere," and "All God's life opens into the individual particular" (James 1982, p. 114). James can even say that Emerson's "total thought" exhibits an "intensely religious character" (James 1982, p. 112).

In Varieties, James speaks about Emerson's religious thought at greater length. Early in the book, James gives his famous definition of religion: "Religion, therefore, as I now ask you arbitrarily to take it, shall mean for us the feelings, acts, and experiences of individual men in their solitude, so far as they apprehend themselves to stand in relation to whatever they may consider the divine" (James 1985, p. 34). Then he turns immediately to the question as to just what counts as "divine," and whether non-theistic principles could be such. According to "Emersonianism," James says, God "evaporate[s] into abstract Ideality ... not a superhuman person, but the immanent divinity in things, the essentially spiritual structure of the universe" (James 1985, p. 34). James quotes Emerson's Divinity School address at some length to elucidate the view that divinity, for Emerson, is the moral "soul of order" of the universe. Whether such soul involves consciousness or not, it "protect[s] all ideal interests and keep[s] the world's balance straight" (James 1985, pp. 34-35). James insists that even if Emerson's perspective construes the cosmic, divine soul as an impersonal, moral structure, it is nevertheless properly considered religious. And experiences of the Emersonian transcendent are properly considered religious experiences: "It would be too absurd to say that the inner experiences that underlie such expressions of faith as this and impel the writer to their utterance are quite unworthy to be called religious experiences" (James 1985, p. 36).

This, then, in outline, are some of the key tenets of what we know about James's view of Emerson's philosophy. How do these ideas square with James's own views about individuality?

\section{James's Individuality}

James, like Emerson, is committed to the sovereignty of the individual. Indeed, he characterizes his philosophy as "individualistic" (James 1992, vol. 8, pp. 521-22). Individuality for James means to appreciate and endorse the various ways in which one person differs from the next, in outlook, upbringing, habit, character, personality, and profession. Whereas communitarians and traditionalists value what people share with one another, individualists like James celebrate and cultivate difference. James, like Emerson, subscribes to the crucial importance of self-reliance. For him, this means that when it comes to our beliefs, our morality, our politics, and our religion, we should treat ourselves as a locus of authority. In Pragmatism, James describes belief acquisition not as a matter of deferring to some authority figure, regardless of how such proposals mesh with our own history, but as a matter of testing candidates for belief against our previous store of beliefs (James 1975, pp. 34-37). This gives our own personal experiences and autobiography a preeminent position over and against any propositions others would try to foist upon us. This is, he says, what gives us our "dignity and ... responsibility as thinkers" (James 1975, p. 123). In terms of the moral and political ideals by which we live, James, like Emerson, rejects the idea that we would live second hand, on the basis of others' ideals that we take uncritically as our own. In his essay, "What Makes a Life Significant," he rejects the idea that one can adopt and follow one's life's ends as a matter of "sodden routine" (James 1983, p. 163). Rather, one's 
ideals must be consciously chosen, "intellectually conceived," meaning that we have reflected upon our lives' teloi and endorsed those that we regard as appropriate for us. One commits oneself to one's ideals, "we are their live champions and pledges" (James 1975, p. 137).

This is true when it comes to religion, too. James's definition of religion in Varieties, recounted above, places central emphasis on individuals and their experiences. James deflects attention away from institutional religion in order to study "personal" religion, in which "the individual transacts the business by himself alone, and the ecclesiastical organization, with its priests and sacraments and other go-betweens, sinks to an altogether secondary place. The relation goes direct from heart to heart, from soul to soul, between man and his maker" (James 1985, p. 32). This is religion first hand. To conform unthinkingly to the rituals and beliefs of tradition is "second-hand" (James 1985, p. 33).

All this talk of the authority of the individual might make it sound as though James subscribes to a view of the individual as independent, unencumbered by social relations, thoroughly autonomous, and atomistic. This is not the case. Neither Emerson nor James sees individuality as the default condition of the human being. Both, in fact, are worried about the opposite, that docility and conformity are far more prevalent. Both see individuality as something that must be worked for and achieved, in a process that requires interrelationality and dependence all the way through, even as it encourages one to cast a reflective and critical eye on the ways in which one is dependent. James recognizes the thorough extent to which we are all social, thoroughly enmeshed in relations of care and dependence. Indeed, he goes so far as to endorse the view that we hardly differ from one another at all, we are so much so products of our day and age. In "The Importance of Individuals," James writes, "An unlearned carpenter of my acquaintance once said in my hearing: 'There is very little difference between one man and another; but what little there is, is very important.' This distinction seems to me to go to the root of the matter" (James 1979, p. 191). To a large extent, our beliefs are a product of our inheritance, the process of socialization we all undergo (James 1975, p. 122). The work we do in exercising epistemic authority over our beliefs is not an act of self-creation, but an act of critical evaluation of the storehouse of beliefs we receive from our society and share with our peers. It is not that we never defer to anyone else's testimony or authority, it is that when we do so, as so often we do, we should do so conscientiously. Our selves are constituted by our socially induced habits and by our friends, peers, families, and possessions (James 1981, vol. 1, pp. 109, 279-81). So James's philosophy is one of sociality as much as of individuality (James 1976, p. 99).

Emerson, too, for all his talk about self-reliance, acknowledges and emphasizes the degree to which we rely on and are formed by our social and historical contexts. He recognizes that who we are is a product of gifts that we have received from others. In Conduct of Life, he notes that individuality requires and exists in dynamic tension with one's sociality: "I must have children, I must have events, I must have a social state and history, or my thinking and speaking want body or basis" (Emerson 1983, p. 1029). In "Experience," he writes, "When I receive a new gift, I do not macerate my body to make the account square, for if I should die, I could not make the account square. The benefit overran the merit the first day, and has overran the merit ever since" (Emerson 1983, p. 491). In "American Scholar," Emerson counts the past as one of the great influences on the mind of the scholar, and by scholar, he means not an exclusive or academic office, but "Man thinking," and this is broad vocation to be sure: "Is not, indeed, every man a student?" (Emerson 1983, p. 54). Emerson recognizes the way that literature, art, institutions, and books shape our intellect and its virtues (Emerson 1983, p. 56). ${ }^{7}$ In "American Scholar," Emerson's self-reliant impulses are in full force. He cautions repeatedly against accepting the influence of the past in place of one's own experience and judgment. But even in doing so, he recognizes the "indispensable" role of the institutions of education and socialization, like colleges, which "gather from far every ray of various genius to their hospitable halls, and, by the concentrated fires, set the hearts of their youth on flame" (Emerson 1983, p. 59).

7 See also the "Culture" chapter in Conduct of Life (Emerson 1983, pp. 1013-34). 
Self-reliant individuals are not self-created or independent of influence or shaping. They take what they have been given, sift through it to discern what they can endorse and what not, and make their own course through life. Both James's and Emerson's construals of self-reliance are aptly described in George Kateb's terms: one is "not the author but the editor of one's self and one's life" (Kateb 2011, p. 10). One does not generate oneself from scratch, but revises the self that one has received from nature and society.

Self-reliance, properly understood, then is as central to James's understanding of the individual as it is for Emerson. Moreover, James like Emerson regards individuality as involving receptive attention. We see this in James's essay, "On a Certain Blindness in Human Beings." The topic of this text is how extremely difficult it is to understand others' values and perspective when they differ from our own. James recognizes that to be able to do so is crucial for the sort of pluralism that he endorses. James's pluralistic ideal does not settle merely for forbearance of the disliked habits of others, but calls for an active appreciation and even celebration of difference. However, we face considerable obstacles to achieving this sort of regard for others. Our own particular profession and station in life limits our cares. We give attention to those things that typically surround us, and especially those things that facilitate the achievement of our goals (James 1983, pp. 138, 141). Teachers attend to their students, their colleagues, the educational institutions in which they work, pedagogy, and curriculum. They don't have time to understand the particular values that guide medicine, or the specific workings of hospitals and clinics. Similar considerations apply to regional, ethnic, racial, and religious identities and practices. Given these limitations, the predictable and all-too-frequent outcome is that we find the values of others distasteful, incomprehensible, and threatening. James sees these conditions as dangerous for democracy (James 1983, p. 4). In addition to the bad consequences for democracy of our egoistic perspective, to regard others by our own standards is to misapprehend their value. As such, this attitude is bad in itself.

James's response to these limitations of our capacity to appreciate others is a strong endorsement of what we have been calling receptive attention. To attend to the inner life of others is to be open to "the mystic sense of hidden meaning" (James 1983, p. 139). By attending receptively, we can encounter others' non-instrumental value in sudden episodes of insight, in a way that undoes our consciousness like the mystics' vision of God did for them: "The vast world of inner life beyond us ... illuminate[s] our mind. Then the whole scheme of our customary values gets confounded, then our self is riven and its narrow interests fly to pieces, then a new centre and a new perspective must be found." This can be so pronounced that James can call it "an epoch" in the subject's "history" (James 1983, pp. 138-39). Walt Whitman (another Emerson protégé), for James, preeminently evidences this sort of sensibility. James quotes Whitman's poem, "Crossing Brooklyn Ferry" at length, in which Whitman describes observing, with a religious sensibility of openness and appreciation, people commuting to and from work (James 1983, pp. 142-43). But such a capacity must be cultivated, it does not come to us naturally, and indeed, our involvement in practical affairs stands in permanent opposition to such sensitivity. James thinks that we can cultivate an appreciation for receptivity to the value of the human other through nature mysticism, and he quotes a number of nature mystics to elucidate this idea, including Emerson (from Nature). James writes,

The occasion and the experience, then, are nothing. It all depends on the capacity of the soul to be grasped, to have its life-currents absorbed by what is given. "Crossing a bare commons," says Emerson, "in snow puddles, at twilight, under a clouded sky, without having in my thoughts any occurrence of special good fortune, I have enjoyed a perfect exhilaration. I am glad to the brink of fear." (James 1983, p. 146)

It is not just Emerson's receptivity toward the hidden value in ordinary situations that James appreciates, but also his understanding of non-instrumental apprehensions of human value. James cites approvingly Emerson's thoughts about falling in love, an especially disruptive way to encounter another person: 
This higher vision of an inner significance in what, until then, we had realized only in the dead external way, often comes over a person suddenly; and when it does so, it makes an epoch in his history. As Emerson says, there is a depth in those moments that constrains us to ascribe more reality to them than to all other experiences. The passion of love will shake one like an explosion, or some act will awaken a remorseful compunction that hangs like a cloud over one's later day. (James 1983, p. 139)

James describes the central message of "On a Certain Blindness" as the "democratic respect for the sacredness of individuality" (James 1983, p. 4), and he views the essay as an expression of his most fundamental commitments. In a letter, he calls it, "the perception on which my whole individualistic philosophy is based" (James 1992, vol. 8, pp. 521-22). So in James's mind, receptive attention is a core tenet of both Emerson's outlook and his own.

Vocation too is an essential aspect of individuality for both. James writes, in "On a Certain Blindness," "Each of us has some specialized vocation of his own" (James 1983, p. 138). The ideals that guide us are ones for which we must risk and sacrifice as we give them expression in our lives: "Although a man always risks much when he breaks away from established rules and strives to realize a larger ideal whole than they permit, yet the philosopher must allow that it is at all times open to any one to make the experiment, provided he fear not to stake his life and character upon the throw" (James 1979, p. 156). When it comes to religious practices, one must find one's own distinctive calling. We should "build out our religion in the way most congruous with our personal susceptibilities" (James 1985, pp. 404-5). "Let us be saints," he says: "Each of us must discover for himself the kind of religion and the amount of saintship which best comports with what he believes to be his powers and feels to be his truest mission and vocation" (James 1985, p. 299).

Individuality is a varied concept. We cannot assume that any two figures who bandy the word about mean the same thing. But, as should now be obvious, when James and Emerson tout the term, they have something strikingly similar in mind. For both of them, individuality centrally involves a notion of self-reliance, conditioned by our relationality; sensitive appreciation of others and the world around us; and a commitment to one's own vocation. But the similarities extend further, and we can see this when we consider the political and religious implications of the individuality that these figures endorse.

\section{The Politics of Individuality}

Because of their individualism, interpreters have accused Emerson and James of being apolitical or insufficiently political. Cornel West charges James with "political impotence" for being too focused on the "personal and existential," and George R. Garrison and Edward H. Madden say that James's "individualism kept him from acting in concert with others through effective organizations to bring to bear cumulative pressure" on social ills (West 1989, p. 60; Garrison and Madden 1977, p. 211). ${ }^{8}$ Many have regarded Emerson in this same light. Furthermore, critics have charged that the religiosity of both Emerson and James is not political in any constructive way. Kateb, for example, finds in Emerson's religiosity-his belief that cosmic divinity underlies particulars—a "maddening" retreat from full self-reliance, which would not cede any authority from the human to the metaphysical (Kateb 2002, p. 81). Grace Jantzen and Charles Taylor both accuse James's individualistic construal of religion of abandoning the public realm of politics for subjective interiority (Jantzen 1989, p. 301; Jantzen 1995, p. 346; Taylor 2002, pp. 80, 96).

To be sure, much of what makes individualism significant for both Emerson and James involves values that are not explicitly and obviously political. Both Emerson and James, for example, think that perceiving and acting in a truthful way, a way devoid of error and illusion, is a value in its own

8 A number of studies have emerged in the past few decades to correct this understanding of James's philosophy. See for example, (Albrecht 2012; Bush 2017; Coon 1996; Cotkin 1994; Koopman 2005; Miller 1997). 
right, whatever its political implications. Both think that this sort of truthfulness requires trust in one's own experience as opposed to subordinating oneself to history, community, or institutions. This sort of perception involves both self-reliance and receptive openness. Both think that one's vocation can involve values that are not reducible to politics: aesthetics, friendship, family, profession, and so on. Both care about the way that religion confers moral and existential significance on the world and human life therein. Without intending to detract from the non-political import of individuality in James and Emerson, my goal here is to show some common ways in which their individualism is political and the way in which religion is bound up in the politics of individuality. Here are the common points between James's political individualism and Emerson's (as James understands it): first, both think of individualism as involving a responsibility not to conform to evil social, political, and economic arrangements; second, both think of it as involving an ethics of exemplarity; and third, both think of individualism as requiring political arrangements that are non-dominating.

One contemporary influential strand of Emerson scholarship emphasizes as preeminent Emerson's commitment to non-conformity. In The Inner Ocean, Kateb analyzes Emersonian individuality as coming in positive, negative, and impersonal forms (Kateb 1992). The negative form is to avoid complicity with evil, especially evil institutions and social relationships. One attends to the various practices in which one is embedded and to the results of the practices. If the results involve the unjust infliction of harm, then one disembeds oneself from the practices (Kateb 1992, p. 88). The positive aspect of individuality is, in words that James would appreciate,

to take responsibility for oneself-one's self must become a project, one must become the architect of one's soul. One's dignity resides in being, to some important degree, a person of one's own creating, making, choosing, rather than in being merely a creature or a socially manufactured, conditioned, manipulated thing: half-animal and half-mechanical and therefore wholly socialized. Living a life is not like going through motions. (Kateb 1992, p. 90)

The impersonal aspect involves transcendent, ecstatic episodes of receptivity to beauty in others and in the natural world (Kateb 1992, pp. 90-93). Of these three aspects of individuality, the one most relevant to democratic political theory, for Kateb, is the first, that of non-complicity. This makes Kateb's Emerson squeamish about political action. Kateb acknowledges Emerson's active involvement in the abolition movement, so in extreme cases, participation in collective action is necessary, but in general, participating in politics or social movements saps democratic individuality by fostering conformity and subordination (Kateb 1992, pp. 100-5; Kateb 2002, chp. 6).

Jack Turner's account of democratic individuality, like Kateb's, looks at Emerson, but Turner extends and complicates the conversation in important ways by including Frederick Douglass, Ralph Ellison, and James Baldwin. These latter three, as African Americans, speak from a perspective that Emerson and James do not: "the experience of trying to achieve [democratic individuality] in the face of systematic subjugation" (Turner 2012, p. 9). Like Kateb, Turner finds the core element of democratic individuality in Emerson to be non-complicity. Alongside that is self-assertion, which corresponds closely to what Kateb calls the positive aspect of individuality. However, Turner works to formulate a conception of individuality that is not in tension with collective political action. He finds this in Douglass's, Ellison's, and Baldwin's promotion of a sense of responsibility toward one's fellow citizens, especially those who are excluded and marginalized. While Emerson construes individuality in terms of nonexploitation - the injunction not to be complicit in social evil—Douglass, Ellison, and Baldwin give us the "democratic egalitarian obligation," the obligation "to contribute to the common effort to ensure that all democratic citizens have self-reliance's material prerequisites" (Turner 2012, p. 45).

Alex Zakaras's study on Emersonian individualism has its particular concern with the prospects for democratic citizenship in large-scale societies, where people tend to feel ineffective, given the passivity of the average voter in light of their remoteness from the centers of political power, which are controlled by big parties, big money, and big media corporations. Zakaras takes as the primary problem confronting citizenship, then, to be docility. People do not exercise responsibility for the 
political arrangements of their society, often because they feel they have no means or opportunity to do so. Zakaras proposes the development of individuality as a response to docility. Like Kateb and Turner, Zakaras sees non-complicity as a defining feature of Emersonian individuality. However, he, like Turner, is not satisfied with Kateb's discomfort with collective political action. For Zakaras, what generates an obligation to engage in social and political reform is the fact that the extent of our complicity is much greater than Kateb indicates, and so there is no space to which we can withdraw in order to keep our hands clean. We are situated in various harmful and unjust economic and political processes, involving the natural environment, immigrants, warfare, substandard education policies, global poverty, and so on. The obligation not to be complicit in social evil requires not withdrawal, but active participation in efforts to reform the various processes and institutions in which we participate (Zakaras 2009, pp. 212-15).

Certainly James sees non-complicity as central to Emersonian individuality. Emerson is at his "hottest" in his "non-conformist persuasion" (James 1982, p. 111). We have already seen James's endorsement of the first-hand life, one that is not given over to routines uncritically received. We have seen that James, using the same terminology as Emerson, rejects second-hand living and performing routines uncritically. For James as for Emerson, the political dimension of this is to remove oneself from structures of oppression. James lauds those with the moral fiber to devote themselves to "unpopular causes," the "revolutionary or reformatory ticket," to "set free [their] generation" (James 1985, p. 293). In a letter, James pits the individual against the "machine" and warns of acquiescence to evil: "The individual, as soon as he realizes that the machine will be irresistible, acquiesces silently, instead of making an impotent row ... We defend our rotten system. Acquiescence becomes active partnership." 9 In another letter, he warns, "The bigger the unit you deal with, the hollower, the more brutal, the more mendacious is the life displayed. So I am against all big organizations as such, national ones first and foremost, against all big successes and big results" (James 1992, vol. 8, p. 546). James is not against institutions altogether; rather, the test of a good institution is that it "can be described in individualistic terms," that is, it permits those embedded in the institution to distinguish their own aims from those of the institution and to evaluate critically the operations and ends of the institution (James 1975, p. 285).

The problem, though, with stopping at non-complicity in discussing Emerson's politics, as Kateb, Turner, and Zakaras effectively do, is that doing so indicates that Emersonian individualists are principally concerned with their own individuality. Emerson and James both have a commitment not just to their particular individuality, but to the cultivation of a culture of individuality. A commitment to individuality is not merely a commitment to one's own individuality, rather it is a commitment to doing one's best to foster the individuality of one's fellow citizens as well. Self-reliance is not egotism, it is not preoccupation with one's own life's course and one's own experiences to the exclusion of others'. "The pest of society is egotists," Emerson says in The Conduct of Life. "The man runs round a ring formed by his own talent, falls into an admiration of it, and loses relation to the world" (Emerson 1983, pp. 1016-17). Even the necessary disciplines of solitude that self-reliance involve are for the sake of the public. "Solitude takes off the pressure of present importunities that more catholic and humane relations may appear. The saint and poet seek privacy to ends the most public and universal: and it is the secret of culture, to interest the man more in his public, than in his private quality" (Emerson 1983, p. 1029). James and Emerson both have conceptions of vocation according to which it is the responsibility of citizens to work, in keeping with their distinctive traits and skills, toward the achievement of a public culture of individuality. Such a culture requires the educational, social, and intellectual conditions in which the populace at large has the opportunity and motivation to pursue a specific direction for their own lives.

How do we account for this other-concerned ethics of individuality? Jeffrey Stout has recently provided an alternative reading of Emerson's politics to Kateb, Turner, and Zakaras. In Stout's reading,

9 Quoted in (Coon 1996, p. 91). 
Emerson's ethics and politics centrally have to do with exemplification. In this account, Emersonian individuality in its perfectionist dimensions is a call to achieve excellence in the pursuit of one's ideals and to do so not just for one's own sake, but for the sake of exemplifying the ideals. "To be excellent is to stand for something. It is also to do so before others" (Stout 2014, p. 9). It is not enough to avow allegiance to ideals, to give them lip service. One must express them in one's conduct and character. One's life should demonstrate what it is to have one's actions, emotions, and attention guided by the ideal so that others can observe the ideal concretely and specifically. The point of exemplification, in addition to living for the sake of ideals that are appropriately taken to be ends in themselves, is to foster an appreciation of the ideals in particular and of excellence in general amongst one's peers. We see this especially in Emerson's Representative Men. Influential geniuses have their talents and achievements on exhibit, not so that we would worship them, as is the case for Thomas Carlyle in On Heroes, Hero-Worship \& the Heroic in History, but so that their qualities would spread among the population (Carlyle 1993). The term "representative" speaks of exemplification. What the great man represents is some "idea," or ideal. The value to society of the representative man is the ideal that the man represents (unfortunately, Carlyle, Emerson, and James cannot manage to conceive of women as great in the relevant sense; I retain the term "man" in order not to gloss over their sexism) (Emerson 1983, p. 623). Great men are to "serve us" and "enrich us," to "succor our genius" (Emerson 1983, pp. 618, 620,621, 627). This exemplification is moral, but insofar as the ideals are directly political or have political ramification, it is simultaneously political. And a great number of our ideals, insofar as they concern interpersonal relationships and interactions and such things as justice and suffering, will indeed have political ramifications. Indeed, in her treatment of Emerson's ethics, Emily Dumler-Winckler shows that John Brown, in his efforts to end slavery, serves as one of Emerson's most highly regarded exemplars (Dumler-Winckler 2017, pp. 529-34). The personal and the political are typically interwoven with each other in complicated ways, such that one cannot be fully extricated from the other.

The ethics of non-complicity and of exemplification are not unrelated. An ideal that is not widely shared will likely be controversial or obnoxious to one's peers. Living in accordance with such an ideal will require non-conformity and a willingness to undergo the associated costs of rejection, hostility, and misunderstanding. However, standing for an ideal can straightforwardly impel one into action, personal or collective, in ways that contrast with an ethic that is pre-eminently concerned with non-complicity with evil. One is not merely trying to keep one's hands clean, one is putting them to work in service of the goods to which one is pledged, trying to foster the implementation of these goods in one's society. One hopes to influence others to recognize the value of the ideal in question and one hopes that such recognition will provoke others toward goodness and further them in their pursuit of their own ideals.

In keeping with Stout's reading, James indicates that he sees exemplarity as essential to Emerson's ethics and politics. James emphasizes the Emersonian theme of the ineluctable publicity of our moral commitments. "Character infallibly proclaims itself," James writes, and then quotes Emerson, "[Your thoughts] will flow out of your actions, your manners, and your face ... Don't say things. What you are stands over you the while, and thunders so that I cannot hear what you say to the contrary" (James 1982, p. 113). And the point to the public expression of our character is to have an effect on others, just as is the case with the ethics of exemplarity. From "Spiritual Laws," James quotes Emerson: "Never a magnanimity fell to the ground, but there is some heart to greet and accept it" (James 1982, p. 113). When one lives in accordance with one's ideals, "they publish themselves to the universe" (James 1982, p. 113). In a letter in 1905, James describes "Emersonianism" as the duty to "declare your intuitions, though no other man share them," showing both the public dimension of one's internal commitments and the willingness to be non-conformist if necessary. ${ }^{10}$ In a 1906

10 Quoted in (Perry 1935, vol. 2, p. 399). 
speech at Stanford University, James applied this principle to political matters. Speaking of those in the "anti-war party," James counsels that they

begin at all events by speaking out as individuals, whatever truth, however unpopular, is in you. As Emerson says, "He who will always speak the truth will not fail to find himself in sufficiently dramatic situations," and I may add, warlike situations [that is, involving contestation and conflict, not necessarily physical violence]. The wars of the future must be waged inside of every country, between the destructive and constructive ideals and forces." ${ }^{11}$. (James 1982, p. 252)

James's call here to speak and act on behalf of one's ideals, in this case, the anti-militarism ideal, goes beyond mere non-complicity, it is a call to enter into a discursive contest between proponents of military violence and imperialism and those opposed, attempting to construct non-violent ways to resolve the pugnacious impulse that James sees as ineliminable from human nature.

And does James himself embrace the ethics of exemplarity he sees in Emerson? We see that he does most clearly in his sole extended discussion of morality, which occurs in his essay, "Moral Philosopher and the Moral Life," and also in his account of "great men" in "Great Men and Their Environment." One of James's fundamental political commitments is to meliorism, the improvement of society. "Great Men and Their Environment" and "Moral Philosopher and the Moral Life" make it clear that one primary means by which societies are improved, that is to say, that injustice and preventable suffering are reduced, is through the influence of exemplars.

In "Moral Philosopher and the Moral Life," James supplies a moral theory according to which moral values arise from the demands that people make of one another. These demands generate obligations, prima facie, but they must undergo adjudication with competing demands in order for them to be binding, all things considered. The goal of adjudication should always be to honor as many competing demands as possible. ${ }^{12}$ However, in addition to processes of adjudication, James calls for experimentation, and this experimentation just is a form of exemplification.

See everywhere the struggle and the squeeze; and everlastingly the problem how to make them less. The anarchists, nihilists, and free-lovers; the free-silverites, socialists, and single-tax men; the free-traders and civil-service reformers; the prohibitionists and anti-vivisectionists; the radical darwinians with their idea of the suppression of the weak-these and all the conservative sentiments of society arrayed against them, are simply deciding through actual experiment by what sort of conduct the maximum amount of good can be gained and kept in this world. These experiments are to be judged, not a priori, but by actually finding, after the fact of their making, how much more outcry or how much appeasement comes about. What closet-solutions can possibly anticipate the result of trials made on such a scale? Or what can any superficial theorist's judgment be worth, in a world where every one of hundreds of ideals has its special champion already provided in the shape of some genius expressly born to feel it, and to fight to death in its behalf? The pure philosopher can only follow the windings of the spectacle, confident that the line of least resistance will always be towards the richer and the more inclusive arrangement, and that by one tack after another some approach to the kingdom of heaven is incessantly made. (James 1979, pp. 156-57)

In speaking of the "special champion" or "genius" of particular ideals, James is speaking of individuals and groups who commit to live in accordance to their ideal, and thus testify, in their conduct before the watching world, as to the worthiness (or lack thereof) of the ideal by the results

11 Quoted in (Richardson 2006, p. 474).

12 For a fuller discussion of the ethical theory in "Moral Philosopher and Moral Life," see (Bush 2017, chps. 3-4). 
that their lives achieve. Moral reasoning in the abstract does not make for a convincing moral system, only experimentation and observation do. And these experiments are not the preserve of the saint or moral elite, but for anyone willing to sacrifice for the sake of their ideal: "It is at all times open to any one to make the experiment, provided he fear not to stake his life and character upon the throw" (James 1979, p. 157).

As for James's "Great Men and Their Environment," this essay shares the perspective of Emerson's Representative Men. Great men bring about social change through a dynamic relationship between the leader's qualities and the society's receptivity to those qualities. The genius has "peculiar gifts" and the "power of initiative and origination." The "social environment" adopts the genius and his gifts (James 1979, p. 174). Though James's examples of great men are elite figures, including Emerson, he recognizes that greatness is the proper preserve of the "Joneses and the Smiths" too (James 1979, p. 164). The point of encountering others' greatness is that "each of us may best fortify and inspire what creative energy may lie in his own soul" (James 1979, p. 194). James's hope is that "many geniuses" would come together "in rapid succession": "Blow must follow blow so fast that no cooling can occur in the intervals. Then the mass of the nation glows incandescent" (James 1979, pp. 181-82). Here we see the rhetoric of exemplarity quite directly, in distinction from non-complicity.

Finally, James and Emerson understand their individuality to involve a commitment to non-domination, that is, to contest societal and institutional arrangements that grant any party to have the capacity to exercise inappropriate control over another party, and to support arrangements that allow for people to exercise their input into the circumstances that determine their lives. James expresses this sentiment most succinctly in his Robert Gould Shaw Oration, a speech he gave in 1897 commemorating the commander of a regiment of African American soldiers in the Civil War. There James says, "Our nation has been founded in what we may call our American religion, baptized and reared in the faith that a man requires no master to take care of him, and that common people can work out their salvation well enough together if left free to try" (James 1982, p. 66). James's view that the individual takes priority over the institution ("good systems can always be described in individualistic terms," (James 1975, p. 285)) finds expression in the Oration: "Democracy is still upon its trial. The civic genius of our people is its only bulwark, and neither laws nor monuments, neither battleships nor public libraries, nor great newspapers nor booming stocks; neither mechanical invention nor political adroitness, nor churches nor universities nor civil-service examinations can save us from degeneration if the inner mystery be lost" (James 1982, p. 74). Democracy is a way of life for the common person, not principally a procedure for electing representatives.

In James's view, Emerson shares this commitment to non-domination. In his centenary speech, James quotes a passage from Emerson's journals in which Emerson is discussing his contempt for the character and personality of abolitionists, while supporting their role in pursuing reform. James updates Emerson's reflections to apply them to an issue that exercised him, American imperialism in the Philippines.

[Emerson] might easily have found himself saying of some present-day agitator against our Philippine conquest what he said of this or that reformer of his own time. He might have called him, as a private person, a tedious bore and canter. But he would infallibly have added what he then added: "It is strange and horrible to say this, ... for I feel that under him and his partiality and exclusiveness is the earth and the sea and all that in them is, and the axis around which the universe revolves passes through his body where he stands. (James 1982, p. 115)

For James, both slavery and the US military occupation of the Philippines are violations of the principle of non-domination. Slavery and imperialism are exercises of arbitrary control by one party 
over another. ${ }^{13}$ This violates individualism, which would see all individuals exercising maximal control over their own lives. The implication of Emerson's individualism, in James's estimation, is that the person contesting such domination as slavery and imperialism has tapped into the very moral core of the universe.

\section{Politics and Religion}

Religion, for both Emerson and James, is thoroughly wrapped up in individuality and its relation to politics. On the question of religion, James departs clearly and consciously from Emerson. James understands Emerson's religion as involving a divine, transcendent cosmic soul, a metaphysical monism that stands in some tension with the pluralistic and particularist moments in Emerson's corpus. James's own commitments are firmly on the pluralistic side. And his marginalia in Emerson's writings regard as "against my philosophy" passages in which Emerson speaks of topics that James notated as "'monism,' 'abstract unity,' 'the ONE,' and 'transcendental'" (Carpenter 1939, p. 42). But as we have already seen, James is keen to insist that Emerson's philosophy does count as religious, even if it is not theistic. James refers to Emerson as "once born" (James 1982, p. 218), James's label for those who do not need a radical religious re-orientation or conversion to bring them into a good relation with the universe, because they already stand in such a good relation from the start. James is himself "twice born," he required intervention from above to reconcile him to the world. And this might explain in part why when it comes to James's own religious commitments, he is drawn to what he calls "piecemeal supernaturalism," in which there is a God of the sort that can exert causal influence in particular circumstances (in response to prayer, for example) (James 1985, pp. 409-10). This God, however, need not be the omniscient, omnipotent, omnipresent being of traditional Christian dogma, just so long as it is "both other and larger than our conscious selves ... It need not be infinite, it need not be solitary. It might conceivably even be only a larger and more godlike self, of which the present self would then be but the mutilated expression, and the universe might conceivably be a collection of such selves, of different degrees of inclusiveness, with no absolute unity realized in it at all" (James 1985, p. 413). James's pluralist sensibilities lead him to a sort of theism that rejects Emerson's absolute over-soul.

Nevertheless, both thinkers find great importance in the idea that there is some sort of transcendent principle or entity that exceeds the visible world and gives it existential and moral significance. Both agree that religion is experiential. For Emerson, the divine is something that we intuit in attending properly to our self and to our environment. For James, all manner-a great variety-of sorts of religious experiences transpire. But both see the religious subject as one that is more fundamentally an experiencer and an agent than a believer or an obeyer. Just as is the case for their individualism more generally, which holds that the apprehension of truth is better achieved through self-reliance than through deference to hierarchy or history, so this is also true for religion. This is a matter that should not be reduced to politics. However, neither should we ignore the political dimensions of the subordination of the religious institution and tradition to the individual.

Despite the pronouncements of those who criticize his philosophy of religion, James's religious individuality is not apolitical. ${ }^{14}$ He expounds the political implications of his religious individuality explicitly in Varieties of Religious Experience. One of these is the way that the religious subject relates to the religious hierarchy (politics here is relevant in the broad sense of power relations that inhere in whatever sort of institution, not merely the institutions of the state). James warns of "two spirits of

13 Emerson speaks of slavery in terms of domination in his "Address on Emancipation in the British West Indies" (1844): "We sometimes say, the planter does not want slaves, he only wants the immunities and the luxuries which the slaves yield him; give him money, give him a machine that will yield him as much money as the slaves, and he will thankfully let them go. He has no love of slavery, he wants luxury, and he will pay even this price of crime and danger for it. But I think experience does not warrant this favorable distinction, but shows the existence, beside the covetousness, of a bitterer element, the love of power, the voluptuousness of holding a human being in his absolute control" (Emerson 1995, p. 17).

14 I make the fuller case for the politics of James's religious individualism in (Bush 2017). 
dominion," the spirit of dogmatic dominion, which is the propensity of religious officials to enforce adherence to a particular system of belief, and the spirit of corporate dominion, the propensity of religious officials to exercise power to control the behavior of adherents (James 1985, p. 271). A "genuine first-hand religious experience" and its "spontaneous religious spirit" counteracts and opposes these tendencies. James's religious individualism is so far from being apolitical, it is explicitly a political contestation of institutional power. Religion for James is political in the more conventional, government-centric sense as well. In his view, religion and its experiences supply a specific sort of psychological satisfaction to practitioners that allows them to cope with personal loss in the pursuit of moral and political ideals (James 1985, pp. 45-49; 1979, pp. 159-61). Someone whose experiential religion supplies such motivational resources is not afraid to sacrifice for the sake of political ideals:

Think of the strength which personal indifference to poverty would give us if we were devoted to unpopular causes. We need no longer hold our tongues or fear to vote the revolutionary or reformatory ticket. Our stocks might fall, our hopes of promotion vanish, our salaries stop, our club doors close in our faces; yet, while we lived, we would imperturbably bear witness to the spirit, and our example would help to set free our generation. (James 1985, p. 293)

James then must think that Emerson's religious individuality is also political. Religion for Emerson, in James's account, is to perceive at first hand the cosmic, universal moral structure of the universe in the particulars that surround one. Because James thinks of first-hand religiosity as a political matter, in prioritizing the individual over the institution, we must understand that connection to exist in his statements about Emerson's religious individualism, as when he says, "The present man is the aboriginal reality, the Institution is derivative, and the past man is irrelevant and obliterate for present issues" (James 1982, p. 112). We know from Varieties that for James, this first-hand religiosity, to view oneself and not one's institution as the primary locus of authority, is a matter that is simultaneously epistemic, axiological, aesthetic, and political. Though James is not a transcendentalist in the sense that Emerson is, he would not share Kateb's worry that Emerson's embrace of a universal, divine mind is a cession of authority from the individual, because Emerson's divine mind is not something other than the individual, it inhabits the individual, and the structure of the moral universe is shared by the individual. The individual is continuous with the cosmos, not set over and against it: James writes about Emerson's vision, “The great Cosmic Intellect terminates and houses itself in moral men and passing hours. Each of us is an angle of its eternal vision, and the only way to be true to our Maker is to be loyal to ourselves" (James 1982, p. 111). Apprehending the transcendent moral law is apprehending one's true nature, not abdicating one's authority.

James's reflections on Emerson, though brief, nevertheless supply a significant interpretation of the core views of Emerson's philosophy from someone remarkably well acquainted with Emerson's writings and person. Though my task here has not been to make an extensive case that James's interpretation is faithful to an exposition of Emerson's ideas across his corpus, I have at least hinted along the way that in my view, James's assessment of Emerson's principles do in fact capture Emerson's perspective accurately. Despite their considerable differences in temperament and rhetorical style, it is striking to see how closely James's understanding of individualism resembles Emerson's. Both see self-reliant individuals not as ones who abnegate politics for the sake of their private religiosity or who rest content with the effort to keep their hands untainted, but as committed to discerning a way, through their unique vocation, to foster a society-wide democratic culture, a suitable environment for the citizenry at large to achieve their own individuality.

Conflicts of Interest: The author declares no conflict of interest. 


\section{References}

Albrecht, James M. 2012. Reconstructing Individualism: A Pragmatic Tradition from Emerson to Ellison. New York: Fordham University Press.

Bush, Stephen S. 2015. Religion against Domination: William James's Individualism. Journal of the American Academy of Religion 83: 750-79. [CrossRef]

Bush, Stephen S. 2017. William James on Democratic Individuality. Cambridge: Cambridge University Press.

Carlyle, Thomas. 1993. On Heroes, Hero-Worship \& the Heroic in History. Berkeley: University of California Press.

Carpenter, Frederic I. 1929. Points of Comparison between Emerson and William James. New England Quarterly 2: 458-74. [CrossRef]

Carpenter, Frederic I. 1939. William James and Emerson. American Literature 11: 39-57. [CrossRef]

Cavell, Stanley. 1990. Conditions Handsome and Unhandsome: The Constitution of Emersonian Perfectionism. Chicago: University of Chicago Press.

Coon, Deborah T. 1996. 'One Moment in the World's Salvation': Anarchism and the Radicalization of William James. Journal of American History 83: 70-99. [CrossRef]

Cotkin, George. 1994. William James, Public Philosopher. Chicago: University of Illinois Press.

Dumler-Winckler, Emily J. 2017. The Virtue of Emerson's Imitation of Christ: From William Ellery Channing to John Brown. Journal of Religious Ethics 45: 510-38. [CrossRef]

Emerson, Ralph Waldo. 1983. Essays and Lectures. New York: Literary Classics of the United States.

Emerson, Ralph Waldo. 1995. Emerson's Antislavery Writings. Edited by Len Gougeon and Joel Myerson. New Haven: Yale University Press.

Friesner, Nicholas. 2017. 'From a Calmer Height of Love and Wisdom': Emerson, Religious Sentiment, and Environmental Intimacy. Ph.D. dissertation, Brown University, Providence, RI, USA.

Garrison, George R., and Edward H. Madden. 1977. William James-Warts and All. American Quarterly 29: $207-21$. [CrossRef]

James, William. 1975. Pragmatism. Cambridge: Harvard University Press.

James, William. 1976. Essays in Radical Empiricism. Cambridge: Harvard University Press.

James, William. 1979. The Will to Believe and Other Essays in Popular Philosophy. Edited by Frederick Burkhardt, Fredson Bowers and Ignas K. Skrupskelis. Cambridge: Harvard University Press.

James, William. 1981. The Principles of Psychology. Edited by Fredson Bowers, Ignas K. Skrupskelis and Frederick H. Burkhardt. Cambridge: Harvard University Press, 3 vols.

James, William. 1982. Essays in Religion and Morality. Edited by Frederick Burkhardt, Fredson Bowers and Ignas K. Skrupskelis. Cambridge: Harvard University Press.

James, William. 1983. Talks to Teachers on Psychology and to Students on Some of Life's Ideals. Cambridge: Harvard University Press.

James, William. 1985. The Varieties of Religious Experience. Cambridge: Harvard University Press.

James, William. 1992. The Correspondence of William James. Edited by Ignas K. Skrupskelis and Elizabeth M. Berkeley. Charlottesville: University Press of Virginia, 12 vols.

Jantzen, Grace M. 1989. Mysticism and Experience. Religious Studies 25: 295-315. [CrossRef]

Jantzen, Grace M. 1995. Power, Gender and Christian Mysticism. Cambridge: Cambridge University Press.

Kateb, George. 1992. The Inner Ocean: Individualism and Democratic Culture. Ithaca: Cornell University Press.

Kateb, George. 2002. Emerson and Self-Reliance, new ed. Lanham: Rowman \& Littlefield.

Kateb, George. 2011. Human Dignity. Cambridge: Belknap Press of Harvard University Press.

Koopman, Colin. 2005. William James and the Politics of Personal Freedom. Journal of Speculative Philosophy 19: 175-86. [CrossRef]

McDermott, John J. 1982. Introduction. In Essays in Religion and Morality. Edited by Frederick Burkhardt, Fredson Bowers and Ignas K. Skrupskelis. Cambridge: Harvard University Press.

McDermott, John J. 2007. The Drama of Possibility: Experience as Philosophy of Culture. Edited by Douglas R. Anderson. New York: Fordham University Press.

Miller, Joshua. 1997. Democratic Temperament: The Legacy of William James. Lawrence: University of Kansas Press.

Perry, Ralph Barton. 1935. The Thought and Character of William James, as Revealed in Unpublished Correspondence and Notes, Together with His Published Writings. Boston: Little, Brown and Company. 
Richardson, Robert D. 2006. William James: In the Maelstrom of American Modernism: A Biography. Boston: Houghton Mifflin.

Slater, Michael R. 2009. William James on Ethics and Faith. Cambridge: Cambridge University Press.

Stafford, William T. 1953. Emerson and the James Family. American Literature 24: 433-61. [CrossRef]

Stout, Jeffrey. 2014. The Transformation of Genius into Practical Power: A Reading of Emerson's 'Experience.' American Journal of Theology \& Philosophy 35: 3-24.

Taylor, Charles. 2002. Varieties of Religion Today: William James Revisited. Cambridge: Harvard University Press.

Turner, Jack. 2012. Awakening to Race: Individualism and Social Consciousness in America. Chicago: University of Chicago Press.

West, Cornel. 1989. The American Evasion of Philosophy: A Genealogy of Pragmatism. Madison: University of Wisconsin Press.

Zakaras, Alex. 2009. Individuality and Mass Democracy: Mill, Emerson, and the Burdens of Citizenship. Oxford and New York: Oxford University Press.

(C) 2017 by the author. Licensee MDPI, Basel, Switzerland. This article is an open access article distributed under the terms and conditions of the Creative Commons Attribution (CC BY) license (http://creativecommons.org/licenses/by/4.0/). 